\title{
Risk Factors for Breast Cancer of Different Age Groups: Moroccan Data?
}

\author{
Fatima Zahra Laamiri' ${ }^{\text {, Abdellatif Bouayad }}{ }^{2}$, Nadia Hasswane ${ }^{3}$, Samir Ahid ${ }^{4}$, \\ Mustapha Mrabet ${ }^{1}$, Barkat Amina ${ }^{1}$ \\ ${ }^{1}$ Faculty of Medicine and Pharmacy/Research Team in Maternal and Child Health and Nutrition, Mohammed \\ V University, Rabat, Morocco \\ ${ }^{2}$ Laboratory of Immunology, Institut Pasteur of Morocco, Casablanca, Morocco \\ ${ }^{3}$ Faculty of Medicine and Pharmacy/Hospital Sidilahsen, Temara, Morocco \\ ${ }^{4}$ The Faculty of Medicine and Pharmacy and the Pharmacy Unit at the National Institute of Oncology, Rabat, \\ Morocco \\ Email: barakatamina@hotmail.fr, Fatilamir1970@yahoo.fr, abdellatifbouayad@hotmail.fr, \\ nadiahasswane@yahoo.fr, S.ahid@um5s.net.ma
}

Received 4 December 2014; accepted 28 January 2015; published 30 January 2015

Academic Editor: Chris Constantinou, Stanford University Medical School, USA

Copyright (C) 2015 by authors and Scientific Research Publishing Inc.

This work is licensed under the Creative Commons Attribution International License (CC BY). http://creativecommons.org/licenses/by/4.0/

(c) $\underset{\mathrm{EY}}{\mathrm{B}}$ Open Access

\begin{abstract}
Background: Several epidemiological studies have been carried to identify the risk factors for developing breast cancer. The aim of this study was to evaluate the risk factors associated with breast cancer in different age groups in the Moroccan women and to determine susceptible and protective factors. Methods: This was a case control study including 400 women with breast cancer and 400 controls of the National Institute of Oncology Sidi Mohamed Ben Abdallah, Rabat, Morocco from 2008 to 2010 . These women were interviewed for epidemiological information and risk factor for breast cancer. Results: Early age at menarche, late menopause, oral contraceptive and family history with first degree were positively associated with breast cancer in all the series and in the age group between 22 and 34 years. In the age group between 44 and 34 years, a risk of breast cancer was associated only with a family history of breast cancer. In the age group of 45 years or older, the factors which seem to influence a breast cancer are: late menopause, oral contraceptive and family history in the first degree. In contrast, early childbearing, multiparity and lactation were negatively associated with breast cancer. Conclusion: This study is rather in favour of positive association between hormonal factors and breast cancer, and confirms the protective role of multiparity and lactation.
\end{abstract}

\section{Keywords}

Breast Cancer, Risk Factors, Parity, Hormonal Factors, Family History

How to cite this paper: Laamiri, F.Z., Bouayad, A., Hasswane, N., Ahid, S., Mrabet, M. and Amina, B. (2015) Risk Factors for Breast Cancer of Different Age Groups: Moroccan Data? Open Journal of Obstetrics and Gynecology, 5, 79-87.

http://dx.doi.org/10.4236/ojog.2015.52011 


\section{Introduction}

Breast cancer occupies the first place in women because of its high rates of incidence and mortality [1]; it is a hormone-related cancer [2] whose incidence is increasing.

The National Institute of Health and Medical Research estimates that the worldwide incidence of breast cancer has nearly doubled between 1980 and 2005, from 56.8 to 101.5 per 100,000 women mainly in developed countries like West Europe and North America.

In Morocco, breast cancer is the leading type of cancer in women. It is one of the most important public health problems, because the diagnosis is often delayed and the management is difficult and expensive. According to the population register of the Casablanca city, the annual national cancer incidence is estimated at 35,000 new cancer cases a year of which only 12,000 are supported.

However, this incidence tends to decrease in recent years due to a prevention tool that has so far proven effective in reducing mortality from breast cancer namely mammography screening and by stabilizing several risk factors (late age at first pregnancy, breastfeeding less...).

Breast cancer is a clinically heterogeneous and complex disease [3]. Several risk factors are known: age (incidence increased after age 30), family history related to the BRCA1 or BRCA2 genes (5\% of all cancers), endogenous hormonal factors (early age at menarche, late menopause), exogenous hormonal factors (oral contraceptives, hormone replacement treatment), reproductive factors (not pregnant or late pregnancies after 30 years, not breastfeeding), family history of breast cancer, exposure to ionizing radiation, oral contraceptives, hormone replacement therapy for menopause, obesity and dietary factors [4]. Among the factors cited above, some are associated with an increased risk of breast cancer; others are considered protective factors.

Therefore, the acquisition of basic knowledge on the mechanisms of oncogenesis related to these factors is an essential scientific direction for the improvement of current therapies and the development of new therapeutic approaches.

The aim of our study was to analyze the relationship between risk factors and breast cancer in different age groups of Moroccan women with breast cancer compared to healthy controls. Then it discussed the developments of these risk factors and biological basis of disease using data from recent publications.

\section{Patients and Methods}

\subsection{Recruitment of Cases and Controls}

We conducted a case-control study at the National Institute of Oncology Sidi Mohamed Ben Abdallah, Rabatin which we included a population of Moroccan women (collected between December 2008 and December 2010) we have divided into two groups, a group of women with breast cancer, and a group of breast cancer-free controls.

\subsection{Inclusion Criteria}

Recruitment of cases of breast cancer was based on a diagnosis of breast cancer confirmed by mammography, biopsy and/or surgery by specialists of the National Institute of Oncology. Women recruited and respondents must be of all ages and must be patients newly diagnosed as breast cancer, controls recruited at the same Institute within the framework of the cancer screening campaign organized by government authorities after having undergone a mammography that showed no signs of breast cancer.

To ensure maximum comparability between cases and controls and to ensure representative of the study population each case was matched with one control of the same age we did correspond to each case a witness of the same age. The subjects recruited for this study were aged between 22 and 75 years and were divided into three age groups (22 - 34 years, 35 - 44 years, 45 years and over).

\subsection{Exemption Criteria}

We excluded from the study all women with chronic pathology associated, such as high blood pressure, diabetes and coronary heart disease, women who not within the age rank of 22 - 75 years and patients who were prescribed a treatment (chemotherapy, radiation therapy, hormone therapy). 


\subsection{Background Questionnaire}

The information was gathered from a baseline questionnaire that has been evaluated and tested by our research team, which was administered in a standardized manner to cases and controls. The information collected were for a certain number of risk factors implicated in mammary carcinogenesis and have been the subject of several epidemiological studies. The risk factors identified were: (1) age, (2) menopausal status, (3) age at menopause, (4) body mass index, (5) the age at menarche, (6) age at first full term pregnancy, (7) the number of children, (8) the duration of breastfeeding for each child, (9) oral contraceptives, (10) the hormone replacement therapy, (11) family history and (12) exposure to irradiation. To meet the objective of our study we formed three groups of women according to age: (i) resolve 22 - 34 years, (ii) resolve 35 - 44 years, (iii) slice 45 years and over and we tried to study in each of these groups a number of population risk factors implicated in mammary carcinogenesis and having made the subject of a number of epidemiological studies.

\subsection{Statistical Analysis}

Risk factors collected in survey forms were carried out using SPSS 13.0 software (SPSS Inc., Chicago, IL, USA). The quantitative variables were expressed as mean value and standard deviation. The qualitative variables were expressed as percentages. The comparisons used were the student's t-test, for quantitative variables, and the Pearson $\mathrm{Chi}^{2}$ test, for qualitative variables. The total group of Breast cancer women as well as different age subgroups was separately compared with the control group.

To identify susceptible and protective factors associated with breast cancer, comparisons between groups (women with breast cancer and breast cancer-free controls) were conducted using univariate logistic regression. The first level of significance was 5\% and there was a confidence interval of 95\%.

\subsection{Ethical Considerations}

Respect for the anonymity and confidentiality of information was strictly adhered to. Informed consent was signed before the inclusion of women in the study.

\section{Results}

Eight hundred women were included in this study and were divided into two populations: a population of 400 women with breast cancer and a population of 400 women who were breast cancer-free.

Results of the general settings of the population are presented in Table 1. No statistically significant differences between women with breast cancer and control subjects were observed for average age. The mean BMI was significantly higher in the patient group $\left(28.35 \pm 4.36 \mathrm{~kg} / \mathrm{m}^{2}\right.$ vs $\left.24.4 \pm 3.22 \mathrm{~kg} / \mathrm{m}^{2} ; p<0.001\right)$.

The distribution of patients according to menopausal status shows that the frequency of menopausal women in the patient group is statistically higher than in the control group (64\% versus $40 \% ; p<0.001$ ). In addition, there was a significant difference in the number of children between the two groups ( $3.97 \pm 2.17$ births in controls vs $2.81 \pm 2.20$ births in patients; $p<0.001$ ).

Moreover, the percentage of women whose term of contraception is more than 6 months was statistically higher in the patient population compared with controls (24.8\% versus $13.5 \%$; $p<0.001)$.

We compared the distribution of hormonal risk factors in women with breast cancer as compared with controls (Table 2). Examination of overall results and the age subgroup between 22 and 34 years revealed a highly significant increase frequency of women with early age of periods (below 12 years) in the breast cancer patients, in comparison to controls ( $29 \%$ vs $19.8 \% ; p=0.002$. and $31.7 \%$ vs $9.4 \% ; p=0.02$ respectively).

The overall frequency of women through menopause at a late age (over 55 years) was significantly higher among patients compared with control ( $24 \%$ vs $6 \% ; p<0.001)$. Interestingly, this frequency was significantly higher in the bracket above 45 years $(41.4 \%$ vs $10.7 \%$; $p<0.001)$. The frequency of women who took oral contraceptives over 6 months was significantly higher in the patient group as compared with controls: in the overall series $(24.8 \%$ versus $13.3 \% ; p<0.001)$ and in the range of greater than 45 years old $(32.9 \%$ vs $17 \%$; $p<0.001)$.

The reproductive factors of breast cancer by age subgroup are presented in Table 3 . The frequency of women with older age at the first full-term pregnancy ( $\geq 30$ years) was higher in the patient population $(41 \%$ vs $19 \% ; p<$ 0.001). Furthermore, we also found that nulliparous and women who never breastfed their children were higher in the patient population as compared with controls ( $25.5 \%$ vs $13.3 \%$; $p<0.001$ and $26.8 \%$ vs $13 \% ; p<0.001$. respectively). 
Table 1. Demographic and epidemiological characteristics of control and breast cancer patients ${ }^{\mathrm{a}}$.

\begin{tabular}{|c|c|c|c|}
\hline & Control patients & Breast cancer patients & $p$-value \\
\hline Characteristics & $\mathrm{n}=400(\%)$ & $\mathrm{n}=400(\%)$ & \\
\hline Age group (mean \pm SD years) & $45.51 \pm 11.25$ & $45.83 \pm 11.05$ & 0.685 \\
\hline \multicolumn{4}{|l|}{ Age group (years) } \\
\hline $22-34$ & $64(16)$ & $60(15)$ & 0.843 \\
\hline $35-44$ & $112(28)$ & $108(27)$ & \\
\hline 45 and over & $224(56)$ & $232(58)$ & \\
\hline $\mathrm{BMI}^{\mathrm{b}}\left(\mathrm{Kg} / \mathbf{m}^{2}\right)$ & $24.40 \pm 3.22$ & $28.35 \pm 4.36$ & $<0.001$ \\
\hline Age at menarche (mean \pm SD years) & $12.31 \pm 1.39$ & $11.98 \pm 1.59$ & 0.002 \\
\hline Age at menopause (mean \pm SD years) & $51.28 \pm 2.74$ & $50.22 \pm 5.55$ & 0.025 \\
\hline \multicolumn{4}{|l|}{ Menaupausalstatus (\%) } \\
\hline No & $240(60)$ & $144(36)$ & $<0.001$ \\
\hline Yes & $160(40)$ & $256(64)$ & \\
\hline Number of children (mean \pm SD years) & $3.97 \pm 2.17$ & $2.81 \pm 2.20$ & $<0.001$ \\
\hline \multicolumn{4}{|l|}{ Contraception (\%) } \\
\hline Never & $96(24.1)$ & $102(25.5)$ & $<0.001$ \\
\hline Lessthan six month & $250(62.7)$ & 199 (49.9) & \\
\hline Abovesix month & $54(13.5)$ & $99(24.8)$ & \\
\hline \multicolumn{4}{|l|}{ Type of contraception (\%) } \\
\hline Hormonal & 100 & 100 & \\
\hline Barrier & 0 & 0 & \\
\hline
\end{tabular}

${ }^{\mathrm{a}}$ Values are expressed as mean \pm standard deviation or in count and percentage; ${ }^{\mathrm{b}} \mathrm{BMI}$ : body mass index.

Table 2. Hormonal factors in the overall series and in different age groups of control and breast cancer patients ${ }^{\mathrm{a}}$.

\begin{tabular}{|c|c|c|c|c|c|c|c|c|c|c|c|c|}
\hline Characteristics & $\begin{array}{c}\text { Age group } \\
22-34 \\
\text { years }\end{array}$ & & & $\begin{array}{l}\text { Age group } \\
35 \text { - } 44 \text { years }\end{array}$ & & & $\begin{array}{l}\text { Age group } \\
45 \text { years } \\
\text { and over }\end{array}$ & & & $\begin{array}{l}\text { Overall } \\
\text { series }\end{array}$ & & \\
\hline & $\begin{array}{l}\text { Control } \\
\text { patients } \\
\mathrm{n}=64(\%)\end{array}$ & $\begin{array}{c}\text { Breast } \\
\text { cancer } \\
\text { patients } \\
\mathrm{n}=60(\%)\end{array}$ & $p$ & $\begin{array}{c}\text { Control } \\
\text { patients } \\
\mathrm{n}=112(\%)\end{array}$ & $\begin{array}{c}\text { Breast } \\
\text { cancer } \\
\text { patients } \\
\text { n = } 108 \\
(\%)\end{array}$ & $p$ & $\begin{array}{c}\text { Control } \\
\text { patients } \\
\mathrm{n}=224(\%)\end{array}$ & $\begin{array}{c}\text { Breast } \\
\text { cancer } \\
\text { patients } \\
\mathrm{n}=232(\%)\end{array}$ & $p$ & $\begin{array}{l}\text { Control } \\
\text { patients } \\
\text { n= } 400 \\
(\%)\end{array}$ & $\begin{array}{c}\text { Breast } \\
\text { cancer } \\
\text { patients } \\
\text { n = 400 } \\
(\%)\end{array}$ & $p$ \\
\hline \multicolumn{13}{|l|}{ Ménarche } \\
\hline$<12$ years & $6(9.4)$ & 19 (31.7) & 0.02 & 21 (18.8) & 27 (25) & 0.262 & $52(23.2)$ & $70(30.2)$ & 0.093 & 79 (19.8) & 116 (29) & 0.002 \\
\hline$\geq 12$ years & 58 (90.6) & $41(68.3)$ & & $91(81.3)$ & $81(75)$ & & 172 (76.8) & 162 (69.8) & & $321(80.3)$ & $284(71)$ & \\
\hline \multicolumn{13}{|l|}{ Ménopause } \\
\hline$<55$ years & $0(0)$ & $0(0)$ & & $3(2.7)$ & 28 (25.9) & & 133 (59.4) & 132 (56.9) & $<0.001$ & $136(34)$ & $160(40)$ & $<0.001$ \\
\hline$\geq 55$ years & $0(0)$ & $0(0)$ & & $0(0)$ & $0(0)$ & & $24(10.7)$ & 96 (41.4) & & $24(6)$ & $96(24)$ & \\
\hline Never & $32(50)$ & 44 (73.3) & 0.017 & $28(25.2)$ & 32 (29.6) & 0.142 & 36 (16.1) & $25(10.8)$ & $<0.001$ & $96(24.1)$ & 102 (25.5) & $<0.0001$ \\
\hline$<6$ month & 30 (46.9) & $14(23.2)$ & & 70 (63.1) & 55 (50.9) & & $150(67)$ & 130 (66.3) & & $250(62.7)$ & 199 (49.9) & \\
\hline$\geq 6$ month & $2(3.1)$ & $2(3.3)$ & & $14(12.5)$ & $21(19.4)$ & & 38 (17) & 76 (32.9) & & 54 (13.5) & 99 (24.8) & \\
\hline \multicolumn{13}{|l|}{$\begin{array}{l}\text { Hormone } \\
\text { replacement therapy }\end{array}$} \\
\hline No & $64(100)$ & $60(100)$ & & 112 (100) & $108(100)$ & & 216 (96.4) & 222 (95.7) & 0.685 & $392(98)$ & 390 (19.75) & 0.634 \\
\hline Yes & $0(0)$ & $0(0)$ & & $0(0)$ & $0(0)$ & & $8(3.6)$ & $10(4.3)$ & & $8(2)$ & $10(2.5)$ & \\
\hline
\end{tabular}

${ }^{\mathrm{a}}$ Values are expressed as count and percentage. 
Table 3. Reproductive factors in the overall series and in different age groups of control and breast cancer patients ${ }^{\mathrm{a}}$.

\begin{tabular}{|c|c|c|c|c|c|c|c|c|c|c|c|c|}
\hline Characteristics & $\begin{array}{c}\text { Age group } \\
22-34 \\
\text { years }\end{array}$ & & & $\begin{array}{c}\text { Age group } \\
35-44 \\
\text { years }\end{array}$ & & & $\begin{array}{l}\text { Age group } \\
45 \text { years } \\
\text { and over }\end{array}$ & & & $\begin{array}{l}\text { Overall } \\
\text { series }\end{array}$ & & \\
\hline & $\begin{array}{l}\text { Control } \\
\text { patients } \\
\mathrm{n}=64(\%)\end{array}$ & $\begin{array}{c}\text { Breast } \\
\text { cancer } \\
\text { patients } \\
\mathrm{n}=60 \\
(\%)\end{array}$ & $p$ & $\begin{array}{c}\text { Control } \\
\text { patients } \\
\mathrm{n}=112(\%)\end{array}$ & $\begin{array}{c}\text { Breast } \\
\text { cancer } \\
\text { patients } \\
\mathrm{n}=108 \\
(\%)\end{array}$ & $p$ & $\begin{array}{c}\text { Control } \\
\text { patients } \\
\mathrm{n}=224(\%)\end{array}$ & $\begin{array}{c}\text { Breast } \\
\text { cancer } \\
\text { patients } \\
\mathrm{n}=232 \\
(\%)\end{array}$ & $p$ & $\begin{array}{l}\text { Control patients } \\
\text { n = } 400(\%)\end{array}$ & $\begin{array}{c}\text { Breast } \\
\text { cancer } \\
\text { patients } \\
\mathrm{n}=400 \\
(\%)\end{array}$ & $p$ \\
\hline \multicolumn{13}{|l|}{$\begin{array}{l}\text { Age at first full } \\
\text { term pregnancy }\end{array}$} \\
\hline No & $28(43.8)$ & 45 (75) & 0.001 & 13 (11.6) & $30(27.8)$ & $<0.001$ & $14(6.3)$ & $28(12.1)$ & $<0.001$ & $55(13.8)$ & 103 (25.8) & $<0.001$ \\
\hline$<30$ years & 35 (54.7) & 13 (21.7) & & 88 (78.6) & $44(40.7)$ & & $146(65.2)$ & 76 (32.8) & & 269 (67.3) & 133 (33.3) & \\
\hline$\geq 30$ years & $1(1.6)$ & $2(3.3)$ & & $11(9.8)$ & 34 (31.5) & & $64(28.6)$ & $128(55.2)$ & & 76 (19) & $164(41)$ & \\
\hline \multicolumn{13}{|l|}{ Number of birth } \\
\hline Nulliparous & $28(43.8)$ & $45(75)$ & $<0.001$ & $12(10.7)$ & 29 (26.9) & 0.002 & $13(5.8)$ & $28(12.1)$ & $<0.001$ & $53(13.3)$ & $102(25.5)$ & $<0.001$ \\
\hline 1 to 2 & 23 (35.9) & $3(5)$ & & $10(8.9)$ & 15 (13.9) & & $0(0)$ & $28(12.1)$ & & 33 (8.3) & $46(11.5)$ & \\
\hline$\geq 3$ & $13(20.3)$ & $12(20)$ & & $90(80.4)$ & 64 (59.3) & & $211(94.2)$ & 176 (75.9) & & 314 (78.5) & 252 (63) & \\
\hline \multicolumn{13}{|l|}{$\begin{array}{c}\text { Duration of } \\
\text { breastfeeding }\end{array}$} \\
\hline Never & 27 (42.2) & $46(75)$ & 0.001 & $12(10.7)$ & 32 (29.6) & 0.002 & $13(5.8)$ & 30 (12.9) & 0.001 & $52(13)$ & 107 (26.8) & $<0.001$ \\
\hline$<6$ month & 20 (31.3) & $3(5)$ & & 15 (13.4) & $14(13)$ & & $11(4.9)$ & 27 (11.6) & & $46(11.5)$ & $44(11)$ & \\
\hline$\geq 6$ month & 17 (26.6) & $12(20)$ & & 85 (75.9) & $62(57.4)$ & & 200 (89.3) & 175 (76.4) & & 302 (75.5) & 249 (62.3) & \\
\hline
\end{tabular}

${ }^{\mathrm{a}}$ Values are expressed as count and percentage.

As shown in Table 4, an excess risk of breast cancer was found in patients with family history as compared with controls $(14.3 \%$ vs $2.8 \% ; p<0.001)$. The risk was higher among age subgroups between $22-34$ years $(p=$ $0.035)$, those 35 - 45 years old $(p=0.049)$, and in those 45 or older $(p<0.001)$.

Results of the univariate logistic regression analysis are presented in Table 5 . We found early age of menarche [OR = 1.66 CI 95\%: 1.196; 2.303], late menopause [OR = 2.360, 95\% CI 1.911; 2.914], family history of first degree $[\mathrm{OR}=11.146,95 \% \mathrm{CI}$ : 2.535; 49.005], the use of a contraceptive pill increases [OR $=1.252,95 \%$ CI $1.014 ; 1.547]$ to be positively associated with breast cancer. In contrast, multiparity (OR $=0.639,95 \%$ CI: 0.533; 0.766], early childbearing age [OR $=0.229$, 95\% CI: $0.163 ; 0.323$, and higher breastfeeding at 6 months [OR $=0.652,95 \% \mathrm{CI}: 0.546 ; 0.780]$ were negatively associated with breast cancer.

No significant association for breast cancer was found for hormone replacement, exposure to radiation and family history of breast cancer among second degree relatives.

\section{Discussion}

In the present case-control study, we found several risk factors associated with breast cancer in a population of Moroccan women.

Firstly, women with early age of menarche are more prone to develop breast cancer than that of the last age of menarche. This association of the early age of menarche was significantly increased in the age subgroup between 22 and 34 years. These findings are in line with other studies [5] [6]. Breast cancer shows a strong linked to the early age of menarche and additional years for age at menarche decreased by 5\% risk of developing breast cancer [7]. The most convincing explanation for the latter remains the hormonal impregnation that exists during the period of activity of the ovaries [8]. This hypothesis is consistent with high estrogen levels after menstruation, which is observed in women who have had their periods early [9].

In our population, late age at menopause was also found to be strongly linked to the presence of breast cancer. This association of late age at menopause is now largely supported by data from 51 epidemiological studies 
Table 4. Family history and health factors in different age groups of control and breast cancer patients ${ }^{\mathrm{a}}$.

\begin{tabular}{|c|c|c|c|c|c|c|c|c|c|c|c|c|}
\hline Characteristics & $\begin{array}{c}\text { Age group } \\
22-34 \\
\text { years }\end{array}$ & & & $\begin{array}{c}\text { Age group } \\
35-44 \\
\text { years }\end{array}$ & & & $\begin{array}{l}\text { Age group } \\
45 \text { years } \\
\text { and over }\end{array}$ & & & $\begin{array}{l}\text { Overall } \\
\text { series }\end{array}$ & & \\
\hline & $\begin{array}{c}\text { Control } \\
\text { patients } \\
\mathrm{n}=64(\%)\end{array}$ & $\begin{array}{c}\text { Breast } \\
\text { cancer } \\
\text { patients } \\
n=60 \\
(\%)\end{array}$ & $p$ & $\begin{array}{c}\text { Control } \\
\text { patients } \\
\mathrm{n}=112(\%)\end{array}$ & $\begin{array}{c}\text { Breast } \\
\text { cancer } \\
\text { patients } \\
\mathrm{n}=108 \\
(\%)\end{array}$ & $p$ & $\begin{array}{c}\text { Control } \\
\text { patients } \\
n=224 \\
(\%)\end{array}$ & $\begin{array}{c}\text { Breast } \\
\text { cancer } \\
\text { patients } \\
\mathrm{n}=232 \\
(\%)\end{array}$ & $p$ & $\begin{array}{c}\text { Control } \\
\text { patients } \\
\mathrm{n}=400(\%)\end{array}$ & $\begin{array}{c}\text { Breast } \\
\text { cancer } \\
\text { patients } \\
n=400 \\
(\%)\end{array}$ & $p$ \\
\hline \multicolumn{13}{|l|}{$\begin{array}{l}\text { Family history } \\
\text { of breast cancer }\end{array}$} \\
\hline No & $64(100)$ & 56 (93.3) & 0.036 & 111 & $102(94.4)$ & 0.049 & 214 (95.5) & 185 (79.7) & $<0.001$ & 389 (97.3) & 343 (85.8) & $<0.001$ \\
\hline yes & $0(0)$ & $4(6.7)$ & & $1(0.9)$ & $6(5.6)$ & & $10(4.5)$ & 47 (20.3) & & $11(2.8)$ & 57 (14.3) & \\
\hline \multicolumn{13}{|l|}{$\begin{array}{l}\text { Breast cancer } \\
\text { among degree } \\
\text { relatives }\end{array}$} \\
\hline First degree & $0(0)$ & $4(6.7)$ & 0.036 & $0(0)$ & $4(3.7)$ & 0.098 & $3(1.3)$ & 38 (16.4) & $<0.001$ & $3(0.8)$ & $46(11.5)$ & $<0.001$ \\
\hline Second degree & $0(0)$ & $0(0)$ & & $1(0.9)$ & $2(1.9)$ & & $7(3.1)$ & $9(3.9)$ & & $8(2)$ & $11(2.8)$ & \\
\hline \multicolumn{13}{|l|}{$\begin{array}{l}\text { Exposure to } \\
\text { irradiation }\end{array}$} \\
\hline No & 63 (98.4) & 58 (96.7) & 0.521 & 107 (95.5) & $106(98.1)$ & 0.270 & 218 (97.3) & $226(97.4)$ & 0.951 & 388 (97) & 390 (97.5) & 0.665 \\
\hline Yes & $1(1.6)$ & $2(3.3)$ & & $5(4.5)$ & $2(1.9)$ & & $6(2.7)$ & $6(2.7)$ & & $12(3)$ & $10(2.5)$ & \\
\hline
\end{tabular}

${ }^{\mathrm{a}}$ Values are expressed as count and percentage.

Table 5. Risk factors for breast cancer analyzed by univariate analysis.

\begin{tabular}{|c|c|c|c|}
\hline Variables & $\mathbf{O R}^{\mathrm{a}}$ & $95 \% \mathrm{CI}$ & $p$-value \\
\hline Early age at menarche ( $<12$ years) & 1.660 & $1.196-2.303$ & 0.002 \\
\hline Late menopause (>55 years) & 2.360 & $1.911-2.914$ & $<0.001$ \\
\hline Oral contraceptive (>6 years) & 1.252 & $1.014-1.547$ & $<0.001$ \\
\hline Hormone replacement therapy & 1.256 & $0.491-3.217$ & 0.634 \\
\hline Early childbearing ( $<30$ years) & 0.229 & $0.163-0.323$ & $<0.001$ \\
\hline Multiparity & 0.639 & $0.533-0.766$ & $<0.001$ \\
\hline Lactation (>6 months) & 0.652 & $0.546-0.780$ & $<0.001$ \\
\hline $\begin{array}{l}\text { Family history of breast } \\
\text { First degree }\end{array}$ & 11.146 & $2.535-49.005$ & 0.001 \\
\hline Second degree & 0.641 & $0.255-1.613$ & 0.345 \\
\hline Exposure to irradiation & 1.206 & $0.515-2.825$ & 0.666 \\
\hline
\end{tabular}

Odds ratio has been adjusted for age by univariate logistic regression. Significance threshold $p<0.05$. ${ }^{\text {a }}$ These results were statistically significant; CI, confidence interval.

conducted by the collaborative group on hormonal factors in breast cancer [10], which suggested that late menopause increases the risk of breast cancer by prolonged ovarian hormone production.

One of the striking findings of the present study is that the risk of breast cancer is increased with oral contraceptives beyond 6 months. Indeed, the extensive use of contraceptives at a late age of reproductive life leads to a significant increase of developing breast cancer [11].

No association was observed between breast cancer and hormone replacement therapy. Conflicting results have been reported regarding this result.

Another important finding of the present study is that, early age at first pregnancy, multiparity and lactation 
were negatively associated with breast cancer suggested a protective effect of these factors for breast cancer. A protective role of the multiparity was consistent with the data in the literature that considers multiparity as a protective factor in breast carcinogenesis.

Despite the fact that in the five years following a transient increase in risk of breast cancer was associated with pregnancy in the five years following it [12], it is notable that pregnancy is a protective effect in long-term [13]. Several mechanisms by which multiparity influences the risk of breast cancer are known or suspected. Reproductive period seems to have a double effect: the risk is increased immediately after delivery [14] and then gradually decreases. Pregnancy causes accelerated differentiation of breast tissue and rapid proliferation of the epithelium. The changes initiated during the first pregnancy, especially if it occurred earlier, are enhanced by each of subsequent pregnancies, and development of breast cancer is related to the rate of proliferation of mammary epithelial cells and inversely with the degree of differentiation [15].

The protective role of parity increases proportionately with the number of children and the early age at first birth. Thus, a first pregnancy before 30 years reduces the risk by $25 \%$ compared to a woman who has not had children [16].

In our study population, the frequency of women having their first full term pregnancy at an early age (below 30 years) was significantly decreased in the patient population compared to the control population. This decrease was also observed in a different age of our study population groups. Furthermore we found that early maternal age decreases by $23 \%$ the risk of breast cancer. Thus, women who have their first full term pregnancy before age 30 have an average risk of breast cancer decreased by 25\% compared to nulliparous women [17], the protective effect of multiparity seems to increase proportionally the number of births [14]. Breastfeeding as a protective factor is still debated [18]. The effect of breastfeeding on the risk of breast cancer has been the subject of several studies and the results are controversial. Women who breastfed for a total of at least 25 months have a reduced risk of 33\%, compared to those who never breastfed [19]. The risk of breast cancer is reduced by more than $4 \%$ for each nursing period 12 months [19], and this reduction in risk is higher among young women than among older women [9]. Thus the protective effect of breastfeeding increases with duration of breastfeeding. This inverse association between breastfeeding and the risk of breast cancer can be explained by the following biological mechanisms:

-Lactation can suppress the occurrence and development of breast cancer by reducing estrogen levels and increased prolactin production, which are supposed to reduce cumulative exposure to estrogen in women [2].

-On the other hand it has been shown that the level of estrogen in the blood of lactating women gradually increases from the last birth and continues for several years before they reach the level that is recorded in nulliparous women [20].

-The $\mathrm{pH}$ of milk from the breasts of women who have not breastfed are significantly elevated compared to that from the breasts of women who have breastfed. During lactation, milk is acidic. The epithelial cells, in an alkaline environment, undergo alterations such as hyperplasia, atypia, and increased mitotic activity [21].

-Finally, the protective effect of breastfeeding to be due to its role in the shift of restoring ovulation (risk factor).

It was reported that a family history of breast cancer is strongly associated with breast cancer with a 2 - 3 fold increased risk, suggesting a stronger genetic component, and perhaps stronger associations with specific genes. In our work the risk arising from at last one family history of breast cancer among first degree relatives was elevated among all age groups of female patients compared with control women. This finding is in line with previous reports that found an association of family history with breast cancer. An epidemiological study [22] has highlighted an increased risk of $80 \%$ when there is a history in the first degree, three fold if two first-degree histories coexist and four fold in the event of three or more history [22]. Surprisingly, we did not find familial history among second degree relatives of breast cancer or radiation exposure to be a predictor's risk factor for breast cancer.

There are a few limitations to our study: (a) the number of patients and controls enrolled is small and (b) it is conducted in a shorter period of time than is typical of studies which focus on the similar issues and (c) that it is single centre. However, our study possesses various strengths. One of its strengths lies in providing a platform to bring together more collaborators (clinicians and researchers) to carry out a more in-depth study.

\section{Conclusions}

Our study demonstrates a significant positive association between certain risk factors, in particular those related 
to hyperestrogenism (early age of menarche, age late menopause and use of oral contraceptives) and family history, and breast cancer in Moroccan women. Moreover, we found early age at first full-term pregnancy, multiparity and lactation as the most important protective factors in our population. Nevertheless, these results reinforce, suspicion hormonal factors, factors related to reproduction and genetic factors in the incidence of breast cancer in our country. Their knowledge is essential for public health actions.

Prospective studies in particular those related to environmental factors are needed to individualize the populations where the risk is greater and can be targeted for possible causes.

\section{Competing Interests}

The authors declare that they have no competing interests.

\section{Authors' Contributions}

$\mathrm{AB}$ reviewed the literature, data analysis and interpretation, and helped to draft the manuscript.

\section{Acknowledgements}

We thank all participants for taking part in this study.

\section{References}

[1] Fearly, J., Shin, H.R., Bray, F., Forman, D., Mathers, C. and Parkin, D.M. (2010) Estimates of World Wide Burden of Cancer in 2008: GLOBOCAN 2008. International Journal of Cardiology, 127, 2893-2917.

[2] Key, T.J. and Pike, M.C. (1988) The Role of Oestrogens and Progestagens in the Epidemiology and Prevention of Breast Cancer. European Journal of Cancer and Clinical Oncology, 24, 29 -43. http://dx.doi.org/10.1016/0277-5379(88)90173-3

[3] Einbeigi, Z., Bergman, A., Kindblom, L.G., et al. (2001) A Founder Mutation of the BRCA1 Gene in Western Sweden Associated with a High Incidence of Breast and Ovarian Cancer. European Journal of Cancer, 37, 1904-1909. http://dx.doi.org/10.1016/S0959-8049(01)00223-4

[4] Nkondjock, A. and Ghadirian, P. (2005) Facteurs de risque du cancer du sein. M/S, 21, 175-180.

[5] Richard, A. (2005) Première régles: L’age de survenue en baisse chez les adolescents américains. Journal of Pediatrics, 147, 753-760.

[6] Kotsopoulos, J., Lubinsky, J., Lynch, H.T., et al. (2005) Age at Menarche and the Risk of Breast Cancer in BRCA1 and BRCA2 Mutation Carriers. Cancer Causes Control, 16, 667-674. http://dx.doi.org/10.1007/s10552-005-1724-1

[7] Hunter, D.J., Spiegelman, D., Adami, H.O., et al. (1997) Non-Dietary Factors as Risk Factors for Breast Cancer and as Effect Modifiers of the Association of Fat Intake and Risk of Breast Cancer. Cancer Causes Control, 8, 49-56. http://dx.doi.org/10.1023/A:1018431104786

[8] Clavel-Chapelon, F. (2002) Cumulative Number of Menstrual Cycles and Breast Cancer Risk: Results from the E3N Cohort Study of French Women. Cancer Causes Control, 13, 831-838. http://dx.doi.org/10.1023/A:1020684821837

[9] Key, T.J., Verkasalo, P.K. and Banks, E. (2001) Epidemiology of Breast Cancer. Lancet Oncology, 2, 133-140. http://dx.doi.org/10.1016/S1470-2045(00)00254-0

[10] Collaborative Group on Hormonal Factors in Breast Cancer (1997) Breast Cancer and Hormonal Replacement Therapy: Collaborative Reanalysis of Individual Data from 51 Epidemiological Studies of 52.705 Women with Breast Cancer and 108.411 Women without Breast Cancer. Lancet, 350, 1047-1059. http://dx.doi.org/10.1016/S0140-6736(97)08233-0

[11] Collaborative Groups on Hormonal Factors in Breast Cancer (1996) Breast Cancer and Hormonal Contraceptives: Collaborative Reanalysis of Individual Data on 53.297 Women with Breast Cancer and 100.239 Women without Breast Cancer from 54 Epidemiological Studies. Lancet, 347, 1713-1727.

[12] Liu, Q., Wuu, J., Lambe, M., Hsieh, S.F., Ekbom, A. and Hsieh, C.C. (2002) Transient Increase in Breast Cancer Risk after Giving Birth: Postpartum Period with the Highest Risk (Sweden). Cancer Causes Control, 13, 299-305. http://dx.doi.org/10.1023/A:1015287208222

[13] Merviel, P., Jouvance, O., Naepels, P., Fauvet, R., Cabry-Goubet, R., Gagneur, O. and Gondry, J. (2011) Existe-t-il encore des facteurs de risque de survenue d'un cancer du sein? Gynécologie Obstétrique \& Fertilité, 39, 486-490.

[14] Hinkula, M., Pukkala, E., Kyyronen, P. and Kauppila, A. (2001) Grand Multiparity and the Risk of Breast Cancer: Population-Based Study in Finland. Cancer Causes Control, 12, 491-500. 
http://dx.doi.org/10.1023/A:1011253527605

[15] Russo, J., Hu, Y.F., Yang, X. and Russo, I.H. (2000) Developmental, Cellular, and Molecular Basis of Human Breast Cancer. Journal of the National Cancer Institute Monographs, 27, 17-37. http://dx.doi.org/10.1093/oxfordjournals.jncimonographs.a024241

[16] Ewertz, M., Duffy, S.W., Adami, H.O., Kvåle, G., Lund, E., Meirik, O., et al. (1990) Age at First Birth Parity and Risk of Breast Cancer: A Meta-Analysis of 8 Studies from Nordic Countries. International Journal of Cancer, 46, 597-603. http://dx.doi.org/10.1002/ijc.2910460408

[17] Layde, P.M., Webster, L.A., Baughman, A.L., Wingo, P.A., Rubin, G.L. and Ory, H.W. (1989) The Independent Associations of Parity, Age at First Full Term Pregnancy, and Duration of Breastfeeding with the Risk of Breast Cancer: Cancer and Steroid Hormone Study Group. Journal of Clinical Epidemiology, 42, 963-973. http://dx.doi.org/10.1016/0895-4356(89)90161-3

[18] Lipworth, L., Bailey, R. and Trichopoulos, D. (2000) History of Breast-Feeding in Relation to Breast Cancer Risk: A Review of the Epidemiologic Literature. Journal of the National Cancer Institute, 92, 302-312. http://dx.doi.org/10.1093/jnci/92.4.302

[19] Collaborative Group on Hormonal Factors in Breast Cancer (2002) Breast Cancer and Breastfeeding: Collaborative Reanalysis of Individual Data from 47 Epidemiological Studies in 30 Countries, Including 50,302 Women with Breast Cancer and 96,973 Women without the Disease. The Lancet, 360, 187-195. http://dx.doi.org/10.1016/S0140-6736(02)09454-0

[20] Petrakis, N.L., Wrensch, M.R., Ernster, V.L., Midce, R., Murai, J., Simberg, N. and Sirreri, P.K. (1987) Influence of Pregnancy and Lactation on Serum and Breast Fluid Estrogen Levels: Implications for Breast Cancer Risk. International Journal of Cancer, 40, 587-591. http://dx.doi.org/10.1002/ijc.2910400502

[21] Kennedy, K.I. (1994) Effects of Breastfeeding on Women's Health. International Journal of Gynecology Obstetrics, 47, S11-S20. http://dx.doi.org/10.1016/0020-7292(94)02230-V

[22] Collaborative Group on Hormonal Factors in Breast Cancer (2001) Familial Breast Cancer: Collaborative Reanalysis of Data from 52 Epidemiological Studies of 58209 Women with Breast Cancer and 101986 Women without the Disease. The Lancet, 358, 1389-1399. http://dx.doi.org/10.1016/S0140-6736(01)06524-2 
Scientific Research Publishing (SCIRP) is one of the largest Open Access journal publishers. It is currently publishing more than 200 open access, online, peer-reviewed journals covering a wide range of academic disciplines. SCIRP serves the worldwide academic communities and contributes to the progress and application of science with its publication.

Other selected journals from SCIRP are listed as below. Submit your manuscript to us via either submit@scirp.org or Online Submission Portal.
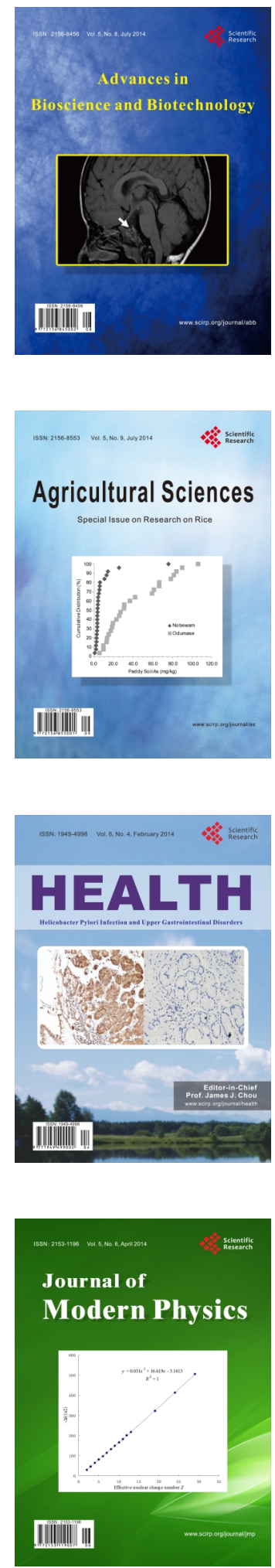
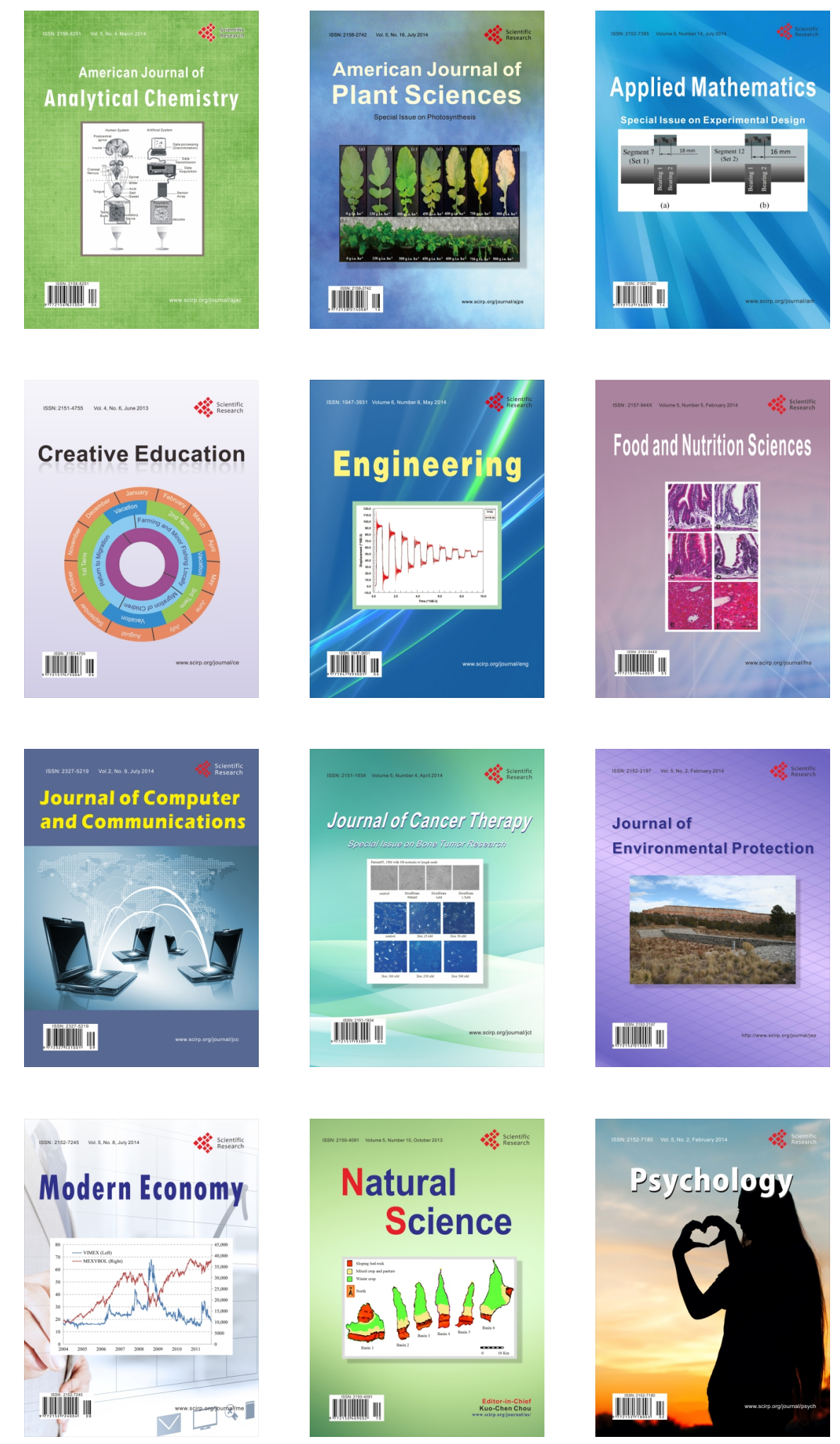